\title{
A discourse analytical view of two South African case studies on the effects on HIV/AIDS in marriage ${ }^{1}$
}

Dr J A van den Berg

Dr J van den Berg Dr R Nichol

Dr B de Klerk (Universiteit van die Vrystaat)

\section{ABSTRACT}

\section{A discourse analytical view of two South African case studies on the effects on HIV/AIDS in marriage}

South Africa is the country with the highest incidence of HIV / AIDS in the world. In order to understand the complex phenomenon experienced by people infected and affected by HIV/AIDS in South Africa, the diverse cultural landscape, amongst other factors, needs to be explored. In a qualitative study, the authors explore the impact of this phenomenon on marriage. Using psychiatric texts and by employing the method of Discourse Analysis on two case studies, different ways of dealing with HIV/AIDS in marriage and the way it dramatically influences marriage are analysed. The impact of these previously untold stories of HIV/AIDS in marriage is seen especially in the lives of spouses who respond differently when managing this problem. In coping with the trauma of HIV/AIDS, spirituality plays a role. Using the biopsychosocial/spiritual-model within a postmodern view of therapy, the role of spirituality is described. The research, viewed through a culture-sensitive lens, acknowledges the different ethical dilemmas involved. Certain limitations in the research methodology are discussed and the need for further research is highlighted.

\section{A DISCOURSE ANALYTICAL VIEW OF TWO SOUTH AFRICAN CASE STUDIES ON THE EFFECTS OF HIV/AIDS IN MARRIAGE}

"To a great extend we are lived by our stories..."

(Griffith and Griffith 2002:84)

1 This article was originally presented at the International Conference “Marriage, Divorce Remarriage”, 18-20 April 2005, Leuven, Belgium. 


\section{INTRODUCTION}

People infected and affected by HIV/AIDS is a dominant part of the diverse demographic and cultural landscape of South Africa. South Africa is the country with the most people infected with HIV/AIDS in the world (UNAIDS 2005:1). To place this statistic in perspective, one must understand that nearly five million South Africans (one in nine of the population) are infected with HIV/AIDS (Dreyer 2002:86). Statistics further indicate that, in South Africa, 20\% of people between the ages of 15-49 are HIV-positive (Müller 2003:2). More closer to home, it is estimated that the highest rate of deaths in South Africa due to HIV/AIDS occurs in the Free State Province (O’Connor 2005:4). These already disturbing data only account for people infected by HIV/AIDS, let alone all the households affected by HIV/AIDS.

Taking into account these facts, as well as research already done from different angles, among others the spiritual (Müller 2003:4-5), on the relationship between the family and HIV/AIDS, we are especially interested, amongst others, in the influence of denial and disclosure of HIV/AIDS on marital life. The reason for this interest is to be found in our different working environments of pastoral and psychiatric care where, on the one hand, the importance of marital life is emphasised, but, on the other hand, we are confronted with the disastrous effects of HIV/AIDS on a daily basis.

\section{RESEARCH PARADIGM}

In adopting a biopsychosocial/spiritual understanding of the relationship between psychiatric and pastoral care, we

...perceive people as holistic beings who have biopsychosocial and spiritual qualities. People are viewed as being interactive and part of family, community, church and society, thus, in continual interaction with their environment. This reflects systemic thinking (Van Niekerk \& Prins 2001:31).

We acknowledge that "Doctor-patient communication in Western medicine has had a troubled history due to the conflict between the doctor's and the patient's world view..." (Cordella 2004:5) and that the biologically-saturated problem description “... can lead people to a sense of themselves and procedures in which they have no active voice ... represent(ing) essential truth...” (Freedman \& Combs 
1996:57). In reaction to this modernistic stance, a more holistic way of interacting with science and people is encapsulated by the postmodern paradigm with an emphasis, amongst others, on the meaning of systems, narratives, and ethical conduct.

Concurrent with the holistic, post-modern paradigm of biopsychosocial/spiritual psychiatric and pastoral care, we as researchers storied our work within the narrative epistemology leading to, amongst others, a narrative practical theology by which, in an ongoing hermeneutical process, the transformation of the human story is opened up (Gerkin 1986:54). Working within a narrative epistemology, we as researchers are aware that Africa and her people live their lives in systems and by stories (Louw 1995:33). Manaka (2001:5) summarises this narrative process through the contention that "in Africa we do things together through stories". By using a narrative practical theology, we honour the shift proposed by an African renaissance that understands human relations beyond limiting criteria (Louw 2001:58). We thus acknowledge the fact that stories are important for Africa and her people, but also that “...the philosophy underlying storytelling...” enables us to “... listen into life... into existence” (Baart 2003:147).

\section{METHODOLOGY}

In this research project, we as a multi-professional research team employed the above-mentioned concept of the biopsychosocial/ spiritual model to not only describe our relationship as researchers and co-researchers (patients), but also our research methodology. Using the qualitative method of a so-called case study, commonly used to describe data within a psychiatric setting, two separate stories of marriages infected and affected by HIV/AIDS are reflected. In line with the sensitivity a narrative epistemology has for the use of words and the meaning of language, we have chosen to employ principles underlying the methodology of discourse analysis to reinterpret the data of the so-called case studies.

Although it may be true that discourse analysis represents a spread of different approaches (Hepburn \& Potter 2004:192), we are attracted to this methodology for its critique on the conventional understanding of the relationship between language and social reality in that “... language represents reality" (Alvesson 2002:67). Drawing on the work of, amongst others, Michel Foucault for whom issues of power are emphasised (Burman et al 1997:2), discourses 
are understood as systems of statements that sustain particular worldviews reflecting a prevailing structure of social and power relationships (Freedman \& Combs 1996:42-43).

The process of making space and the possible loosing up and opening up of discourses that constricts and closes down (Anderson \& Goolishian 1988:381) lead to the formulation of an alternative description (White 1993:39). In this alternative or new description of reality, a so-called "thick description" is formed whereby “... alternative stories can be 'richly described'... opposite of a 'thin conclusion'... of lives and relationships” (Morgan 2000:15).

\section{CASE STUDIES AND DISCUSSION}

By using two texts derived from a psychiatric context, the psychiatric history of two patients with HIV/AIDS and the influence of this diagnosis on their marriages are portrayed. It is important to notice that the description of each of these narratives is employed in a first movement by the clinical case presentation. In a second movement, the psychiatric interpretation of the diagnosis is made. By using principles underlying the method of discourse analysis, the deconstruction of these texts become possible in a third movement leading to a richer understanding of the two narratives reflected in the case studies.

\section{Case study 1}

The patient Sipho (names in all the cases have been changed for ethical reasons) was referred by his family doctor to the psychiatrist, with the diagnosis of acute psychosis. The patient's reality-testing was not intact, he showed episodic aggressive outbursts, and had broken down a door at his home. He was also very suspicious and did not want to see the psychiatrist.

This change in his behaviour was noted soon after he had married his fiancée, Maria. Apparently, the wedding had been a grand occasion with two ceremonies having taken place, one at the bride's home and one in his hometown. During the initial interview, the patient had bizarre thought patterns. He claimed to work for the sake of his identity document. He claimed his new wife would drive him to Lesotho, but he had never been there. His thoughts and pattern of speech were extremely disorganised. At times, he answered questions inappropriately and was unable to do simple arithmetic calculations. 
The following DSM IV diagnosis was made:

Axis 1 Mood Disorder due to a General Medical Condition (HIV) \& Psychotic Disorder due to a General Medical Condition (HIV)

Axis 2 Deferred

Axis 3 Compromised immune system

Axis 4 Marital dysfunction

Axis $5 \quad 31-40$

After initial sedation and anti-psychotic medication, the patient's condition normalised. After informed consent was obtained routine bloods, including blood for sexually transmitted diseases were drawn. Unfortunately blood tests showed signs of immune compromisation and HIV tests proved positive. When the therapist discussed the results with Sipho, he shrugged his shoulders nonchalantly saying, "I had been treated by another specialist doctor, who said I had AIDS, but I just refused to believe him." With Sipho's permission, the therapist invited Sipho's wife, Maria, to visit the hospital consultation rooms and explained her husband's condition, including the psychiatric manifestations, to her. She was encouraged to have an HIV test. Maria felt shocked and angry with Sipho for not telling her. If she had known before hand, the marriage would probably never have taken place.

Terre Blanche (1997:143) alluded to the fact that although a vignette like the one above is informational, it also displays a particular dominant way of articulating. In the words of Anspach (1988:357) “...an arena in which claims to knowledge are made and epistemological assumptions are displayed, a linguistic ritual in which physicians learn and enact fundamental beliefs and values of the medical world"... is created.

Grand narratives, main epistemological strands, explanatory schemas, or discourses and how “... they are put together to perform actions" (Hepburn \& Potter 2004:192) could be identified in the text of the case study(s). In recognising the dominant medical discourse portrayed in the above case study, we are aware and sensitive of the fact that "...western medicine and its diagnosis could become an institution of social control that promulgates the dominant ideologies of society (Chimombo \& Roseberry 1998:234). Sprouting from a discourse analytical way of working with the text, these "truths" 
need to be explored further and challenged in trying to come to terms with a more contextualised and richer meaning of the text. By deconstructing the discourses, a new way of understanding is opened up.

In illustrating this viewpoint, both case studies are described, firstly, by means of some of the dominant discourses visible and, secondly, by deconstructing these dominant "beliefs". (Although the same discourses may be repeatedly found in both case studies, we will only identify it once for the more dynamic reading of the text of this article).

\section{The sexual promiscuous and unfaithful discourse}

In reading the diagnosis and discussion of case study 1 , it would seem as if a dominant discourse of sexual promiscuity and unfaithful behaviour is portrayed. This discourse is in line with "...the connotation of HIV/AIDS with deviant behaviour (homosexuality, promiscuous behaviour) and even to racist attitudes (it's a black disease)" (Dreyer 2002:87). Not only is this true in our minds of this particular case study, but a discourse like this also leads to general assumptions in which "Discourses of AIDS were readily adopted, through associations with promiscuous sexuality, the deviant behaviour of the 'other', and paradoxically, exposure to racist views of 'African AIDS'” (Strebel 1997:115).

The belief that HIV/AIDS only affects certain populations is challenged by research. Ironically, pre-marital sexual relationships are widely accepted in some cultures. Meekers \& Calves (1997:362) explain something of this dilemma by stating that "Unmarried African males commonly have a 'main' girlfriend whom they expect to marry, and one or more other girlfriends, for whom there are no such expectations; some females have similar strategies”. In some of the cultures, it is accepted and even a sign of fertility to have a child before a marriage. Although Sipho's behaviour before marriage played a leading role in him being infected by HIV, it was legitimised in a certain way by his culture. In acknowledging the fact that "Much is written in the literature about the complex and often politically explosive relationship between race, culture and HIV risk" (Bok \& Morales 2001:65), we came to understand that our own culture-background was a filter through which we read the diagnosis. Understanding something of the possible cultural 
influences in Sipho's life brought some new emphases in reading and understanding his position.

\section{The denial discourse}

It is unclear when Sipho first became aware of his HIV status. It is, however, evident that he was not prepared to disclose this knowledge to his new bride-to-be! At first sight, it seems that Sipho was not honest and truthful in the way that he was dealing with the matter. However, as Hendriks (2004:90) is pointing out:

It's a question of differences in culture, differences in worldview. With regard to sexual matters, Western culture is an open culture while almost all-African tribes have a closed culture. They wouldn't speak openly about sexual matters, nor discuss it with their children or wives.

This orientation of Sipho led to his new bride being unaware of his HIV status until the moment that she was being confronted with one of the many manifestations of the HIV illness.

\section{$3 \quad$ The psychosis discourse}

Psychosis brings to mind a mentally disturbed person. An alternative view of the clinical diagnosis would be to acknowledge psychological stress as a contributing factor. In Sipho's case, this could be the impact of the marriage ceremony itself! Marriage in certain cultures in South Africa and Africa consists of various rituals and ceremonies dating over days and even weeks. "Weddings can be very elaborate, involving feasting and dancing for days within a community" (Africaguide 2005:1). The internal conflict in Sipho's life sprouting from the commitment embodied in the marriage ceremony versus the foreseen consequences of being infected by HIV/AIDS contributed to the development of the psychosis. Holt, Court, Vedhara, Nott, Holmes \& Snow (1998:1) rightfully pointed out that "Individuals who choose to disclose their HIV status may have to contend with issues such as discrimination and a disruption in their personal relationships".

\section{$4 \quad$ HIV/AIDS stigmatisation discourse}

It is evident that the effect of a HIV complication had a devastating effect on the Hlobelo-marriage. Maria was rudely confronted with the implications of the commitment made to a husband who did not tell her about his HIV status prior to their marriage. After disclosure, she felt bitter towards Sipho and probably would have divorced him 
if he had not died soon afterwards. Her attitude portrayed the general view of persons towards others infected with HIV/AIDS, leading to stigmatisation and marginalisation, acknowledging “...that people with HIV/AIDS form one of the most oppressed groups in our country, especially since they are both stigmatised and marginalised" (Dreyer 2002:87). Although one tends to sympathise with Maria's position, we could also in hindsight understand Sipho's decision of not telling her about the diagnosis initially. "From the moment scientists identified HIV and AIDS, social responses of fear, denial, stigma and discrimination have accompanied the epidemic" (Frederickson \& Kanabus 2000:1).

\section{Case study 2}

Jack, known with HIV, was brought into the acute male ward at the Free-State Psychiatric Complex in Bloemfontein. He was certified, for he was a danger to himself and to others. He was treated and his psychosis stabilised. The following DSM IV diagnosis was made:

Axis 1 Psychotic Disorder due to a General Medical Condition (HIV)

Axis 2 Deferred

Axis 3 Compromised immune system

Axis 4 Finances, relationship, alcohol abuse

Axis $5 \quad 31-40$

He was later transferred to the medical unit of another hospital, because he had developed an HIV-related confused state or delirium, which was treated with anti retro-viral medication.

During his admission in the ward, I met his wife Erica. In his presence, she informed me that the patient was no longer the man he used to be. She told me that she met this handsome, strong and dynamic policeman 17 years ago. He had the most gorgeous blue eyes, dark hair - and stood out amongst his colleagues regarding his excellent work performance. Their marriage was stable, but Jack periodically abused alcohol and spent too much time with former police colleagues. Stress-related work contributed to his addiction to pleasure-seeking activities. 
The following main discourses are identified in the second case study. Once again, the discourses are identified followed by a possible alternative description.

\section{The marriage is a protection against HIV/AIDS discourse}

Underlying Jack and Erica's disbelief about him being infected by HIV/AIDS is a discourse about marriage being a safeguard against contracting this disease. The question arises how HIV can infect someone who has been in a "stable" marriage of several years. The general belief is that certain single people can be infected by HIV/AIDS and that it does not occur in stable relationships. This general belief system is illustrated by Erica's narrative. She revealed that Jack was transferred to another unit where the colleagues were all married and stable, social, friendship relationships developed. Jack and Erica were both perfectly healthy and after the birth of their baby-girl, the best part of their married life followed. A stockbroker encouraged them to take out an insurance policy. The ensuing blood test results changed their whole world. Jack and his wife were rudely confronted with the existence of HIV. They were both devastated that HIV was fast becoming part of their lives. It is, therefore, acknowledged that marriage as such is not a stronghold against the HIV disease.

\section{The commitment discourse}

The disclosure of Jack's HIV status broadly affected their marital relationship. Soon after the disclosure Jack decided to go on pension to spend more time with his family. Erica felt committed to support her husband even though he had previously been unfaithful to her. Initially, their marriage strengthened; it was like a long vacation. Jack spent hours playing with his little daughter. Jack would not allow Erica to punish their daughter at any stage. Every moment was precious - simply because nobody knew what would happen next.

Research has already indicated that "The burden of HIV in stable relationships places emotional, economic and physical stresses on families” (Tangmunkongvorakul, Celentano, Burke, De Boer, Wongpan \& Suriyanon 1999:1). Erica struggled to keep all the pieces together as she had promised herself. There came a time, however, when this level of her commitment wore thin. She could not cope with Jack as his physical and mental condition deteriorated due to AIDS. As part of a strategy to cope and survive, Erica decided 
to divorce her husband. She arranged a placement for him in a home for HIV infected people. Erica phoned and visited him daily at the hospice, always feeling guilty because she could not care for him herself. Erica's decision challenged the notion of commitment as a dominant discourse, once again emphasising that "There is growing awareness of the importance of holistic treatment for the chronically ill, but there is far less awareness of the independent need of the spouses, relatives of other regular caregivers” (Bloch 2003: 6).

\section{The disclosure discourse}

In contrast to the denial-discourse in the first case study, a discourse of disclosure is well visible in the second case study. Although the disclosure of Jack's HIV status forced the couple to deal with the problem, two important insights are stressed:

Firstly, it would seem that Jack and Erica were disclosing the complete picture of Jack's HIV status. It is, however, evident that there were certain topics which were not revealed. Jack never committed himself to an explanation on why and when he was infected with HIV. Reading carefully and discussing this case study, it comes to mind that the closest Erica came an explanation, was that Jack and his friends dealt with stressful situations by drinking, watching dubious videos, and apparent being involved in promiscuous relationships. Erica had even tried to justify his carousing with friends and their promiscuous life style as a way of dealing with work-related stress.

Secondly, although a discourse of disclosure exists, it would seem that both Erica and Jack had little knowledge about the disease, which lead them to misconceptions about the condition. To quote Erica again: "Neither of us received any counselling related to the effects of this devastating disease on our marriage or ourselves as individuals. Every time he developed a headache or flu, I became hysterical; I thought it was the end!” The lack of knowledge contributed to the fear of disclosing his status. "We would assume that in using more education, a climate could be created in dealing with fear and denial” (Nichol, De Klerk \& Nel 2004:6).

\section{The discrimination discourse}

The Smith-family experienced the widespread effects of discrimination after returning to their hometown. Jack's physical and mental condition deteriorated. They were not accepted in the 
community; they had no friends and suffered the consequences of financial problems. Jack became very depressed, slept most of the time, became increasingly forgetful, and turned to alcohol again.

This specific dominant discourse of discrimination by society is acknowledged by researchers stating that "Social support is an important aspect of psychological adjustment to many people living with HIV infection” (Kalichman, DiMarco, Austin, Luke \& DiFonzo 2003:315). The momentum of the downward spiral affected his work, their intimate relationships, the upbringing of their child, and their social support systems. "The undercurrent of chronic illness is like the volcano: it does not go away. It menaces. It erupts. One damned thing follows another" (Bloch 2003:2).

As an alternative description during counselling, Erica recounted her experience of participating in a home cell-group of a church in Bloemfontein where she had felt accepted. For the first time in her life, she received a great deal of support during the difficult time of her husband's illness. Her self-esteem and her spiritual equilibrium were restored and she was strong enough to face the world again. This testimony of the value of spiritual support is emphasised by Bloch: “... it is important for a well spouse to develop independent spiritual resources and interests, including activities outside the home and activities separate from the patient” (Bloch 2003:7).

\section{CRITIQUE AND POSSIBLE FUTURE DIRECTIONS}

As part of the way in which we are doing research, we are fully aware of possible limitations - which in a certain way can become discourses themselves - that have to be challenged (Terre Blanche 1997:154). By describing some of these possibilities, we not only adhere to the fact that the research could have certain limitations, but by doing so, we also pave the way forward for possible further research.

We are also sensitive to the fact that working in a discourse analytical way “...perhaps a great deal (is) to be learned about ourselves" (Lemke 2004:9). Although it is possible to take a relativist position in using the method of discourse analysis, it is not our intention because we want to take seriously the truth and worth of psychological theories within ourselves. In this, we are concurrent with Foucault, the French philosopher and psychologist, from whose theories of power much of discourse analytical theory is drawn, who 
“... reminds us that it is not enough simply to speak the right language, to participate in the appropriate discourses. We must also find the truth of psychological statements within ourselves" (Burman et al 1987:3). In describing the following contours, we are merely trying to navigate in the landscape of marriages infected and affected with HIV/AIDS using some possible co-ordinates:

\section{The power of words}

We have illustrated that there is much more to words and their meaning that what initially meets the eye. As shown in using the method of discourse analysis, there is much more to understanding the complex phenomenon of marriages infected and affected by HIV/AIDS than just using a biological description. In describing marriages infected and affected by HIV/AIDS, people using a biopsychosocial/spiritual model is "...concerned with different factors that contribute to the development of symptoms..." (Van Niekerk \& Prins 2001:31). In acknowledgement of the fact that “...language contributes to the meaning-making process, by construing experience, constructing social relationship, and creating text” (Mutingl 2004:72), interviews should be constructed in a multidisciplinary way leading to the richest possible formulation of a contextualised narrative.

\section{The possible worth of spirituality}

To our mind, the importance of the spiritual part of the biopsychosocial/spiritual model needs to be further investigated and described. As part of systemic thinking, we adhere to the fact that, due to some of the most influential sources within psychiatry, "The role of spirituality and religion in sickness and health has gained ascendancy in recent years, with some suggesting that it become part of the biopsychosocial model” (Sadock \& Sadock 2003:2).

Being aware of the fact that that there "...are few societies (and persons) in which religion plays no significant role..." (Sadock \& Sadock 2003:899), we especially want to empower patients and clients with the possibility of taking into account a spiritual discourse. Being sensitive on the one hand to the freedom of multiple religious discourses, we are on the other hand also honest with ourselves (and with patients and clients) that being part of the Christian community is informing our own spirituality in both a direct and indirect way. 
Trying to work in an ethical manner, it is important for us to ask about the role of our own spiritual tradition contributing to a possible alternative description of the influence of HIV/AIDS. To start with and to be honest, we must agree that HIV/AIDS is "... one of the problems most neglected by theologians and religious communities in South Africa” (Dreyer 2002:86) and that a closer relationship between spirituality and the care of people infected and affected by HIV/AIDS is imperative. This article is an effort not only to address this issue, but to also point the way forward for possible further research.

Possible directions along the road to the development of a sensitive narrative pastoral theology for marriages infected and affected by HIV/AIDS may be a sensitivity for not making grandiose theological statements of control and power, but to be more contextual, situationally sensitive, and modest in claims and assertions (Müller 2003:7-8). Instead, it would serve our engagements with conversational participants in therapy to always remember:

The goal of therapy is to participate in a conversation that continually loosens and opens up, rather than constricts and closes down. Through therapeutic conversation, fixed meanings and behaviours... are given room, broadened, shifted, and changed (Anderson \& Goolishian 1988:381).

If we could adopt a "Practical theology which is transformative, liberative and contextual” (Dreyer 2002:105), we could provide the space and some of the material to fill up areas of silence dominated by certain discourses (Thiesmeyer 2003:1-2).

\section{Seeking of abstractions}

Part of discourse analysis, as well as other research methodologies, is to guide the formulation of general truths applicable to the field of interest. "Sooner or later discourse analysts all seem to end up with wanting to find repetitive patterns in texts. These they then call 'repertoires', 'devices', 'maps' or 'discourses'” (Terre Blanche 1997:155). Working in a post-modern paradigm, which makes us suspicious about the power-conviction in any absolute truths, we are sensitive to the fact that two contextually-bound case studies alone cannot be used to come to generalised conclusions. 


\section{$4 \quad$ A psychiatric domain}

We acknowledge the fact that the two case studies portrayed in the article are strongly situated within a psychiatric context with its own emphasis on discourse as portrayed in terms of vocabulary and sentence construction (Swartz 2002:48-49). Although not all of the dynamics portrayed may be true of so called "normal marriages" infected and affected by HIV/AIDS, we thought it wise to portray these two case studies because of their qualitative richness in describing the devastating effects of people infected and affected by HIV/AIDS. If this deadly illness contributes to more people being diagnosed with a psychiatric illness and further marginalising them from society, their stories need to be heard and placed in a new frame. If this could be accomplished, more people could position themselves...

...in an alternative, more positive discourse of HIV/AIDS....an alternative view of hopefulness for those infected, a sense of living with, rather than dying from AIDS...A sense that something can be done to reduce the agony of being HIV+ might make individuals feel that knowing their HIV status is worthwhile... in which HIV infection is not a disgrace and those infected need acceptance and care (Strebel 1997:117).

\section{CONCLUSION}

Maria, Sipho's wife, was also later diagnosed as HIV-positive. The vicious spiral of anger and denial had become part of her life too. She does not participate in any support group and does not want to reveal her status to others. Erica, although still mourning her husband's death, is coping with her situation. Her daughter, a strong support system, and her involvement in local church activities are the reason for this. Erica and their daughter were able to reach a certain amount of catharsis at the funeral. She still visits Jack's grave. She now plans to start a support group for the spouses of people living with HIV infections.

As illustrated in the article, only certain dominant discourses are highlighted by the power discourse of medical science. Initially, the medical diagnosis led one to focus only on the person infected by HIV/AIDS. Working within a narrative epistemology, space is opened up to also recognise the position of people affected by HIV/AIDS. As portrayed in the different narratives of the two 
marriages, the outcome of the wives being affected by HIV/AIDS through their husband's infection with HIV/AIDS differs. For Maria, who adopted a position of denial regarding the existence of HIV/AIDS, it perpetuated a downward spiral, which eventually led to her own infection and possibly to the further spreading of the disease. On the other hand, Erica learned to accept her situation of being affected by HIV/AIDS in which she was involved through the infection and death of her husband by HIV/AIDS. This led to her being involved, amongst others, in assisting and supporting other people infected and affected by HIV/AIDS, helping them to cope in a preventative way.

The complexity of people being infected and affected by HIV/AIDS asks for a multilayered-perspective, like embedded in the biopsychosocial/spiritual model in which additional room is opened up to hear alternative discourses. By having an ear and an eye for these untold and unwritten stories of the influence of HIV/AIDS in marriage, the horizon of understanding will be broadened.

\section{Consulted literature}

Africaguide. 2005. African People and Culture - Wedding Ceremonies. The Africa Guide. (http://www.africaguide.com/culture/weddings.htm) 1-4. Retrieved from the World Wide Web on 12 March 2005.

Alvesson, M 2002. Postmodernism and Social Research. Buckingham: Open University Press.

Anderson, H \& Goolishian, H 1988. Human systems as linguistic systems: Preliminary and evolving ideas about the implications for clinical theory. Family Process. 27: 371-393.

Anspach, R R 1988. Notes on the sociology of medical discourse: the language of case presentation. Journal of Health and Social Behaviour 29: 357-375.

Baart, A 2003. The fragile power of listening. Practical Theology in South Africa. 18(3): 139-159.

Bloch, P B 2003. The needs of well spouses of people with kidney failure: A case study. The Internet Journal of Advanced Nursing Practice. Vol 5(2) (http://www.ispub.com/ostia/index.php?/xmlFilePath=journals/ijanp/vol5n2/ spouse.xml) 1-21. Retrieved from the World Wide Web on 25 January 2005.

Bok, M.\& Morales, J 2001. Latino communities in the U.S. and HIV/AIDS. Journal of HIV/AIDS Prevention and Education for Adolescents and Children. 4(1): 61-70.

Burman, E \& Kottler, A \& Levett, A \& Parker, I 1997. Power and discourse: culture and change in South Africa. In: Culture, Power \& Difference. Edited by Ann Levett, Amanda Kottler, Erica Burman \& Ian Parker. Cape Town: University of Cape Town Press, 1-14. 
Chimombo, M P F \& Roseberry, R L 1998. The power of discourse. An introduction to Discourse Analysis. New Jersey: Lawrence Erlbaum Associates Publishers.

Cordella, M 2004. The dynamic consultation. A discourse analytical study of doctor-patient communication. Amsterdam: John Benjamins Publsihing Company.

Dreyer, J S 2002. Justice for the oppressed: The HIV/AIDS challenge. In Divine Justice-Human Justice. Edited by J.S. Dreyer and J.A. van der Ven. Pretoria: Research Institute for Theology and Religion, UNISA, 85-112.

Frederikson, J \& Kanabus, A 2000. HIV \& AIDS Stigma and Discrimination (http://www.avert.org/aidsstigma.htm) 1-6. Retrieved from the World Wide Web on 4 August 2002.

Freedman, J \& Combs, G 1996. Narrative Therapy. The social construction of preferred realities. New York: W W Norton \& Company.

Gerkin, C V 1986. Widening the horizons. Pastoral Responses to a Fragmented Society. Philadelphia: The Westminister Press.

Griffith, J L \& Griffith, M E 2002. Encountering the sacred in Psychotherapy. How to talk with people about their spiritual lives. New York: The Guilford Press.

Hendriks, H J 2004. Studying Congregations in Africa. Wellington: Lux Verbi BM.

Hepburn, A \& Potter, J 2004. Discourse analytical practice. In Qualitative Research Practice. Edited by Clive Seale, Giampietro Gobo, Jaber F Gubrium \& David Silverman. London: SAGE Publications, 180-213.

Holt, R, Court, P, Vedhara, K, Nott, K H, Holmes, J \& Snow, M H 1998. The role of disclosure in coping with HIV infection. AIDS Care 10(1): 49-60.

Kalichman, S C, DiMarco, M, Austin, J, Luke, W \& DiFonzo, K 2003. Stress, Social support and HIV-status disclosure to Family and Friends among HIVpositive men and women. Journal of Behavioral Medicine 26(4): 315-332.

Lemke, J L 2005. Analysing verbal data: Principles, methods and problems. (http://academic.brooklyn.cuny.edu/education/jlemke/papers/handbook.htm) 1-11. Retrieved from the World Wide Web on 23 March 2005.

Louw, D J 1995. Pastoral care for the person with aids in an African context. Practical Theology in South Africa 10(1): 29-44.

Louw, D J 2001. Unmasking the forces behind and beyond - a practical theological assessment of an African renaissance. Practical Theology in South Africa 16(1): 40-61.

Manaka, W L 2001. Despair and hope amongst inmates in prison: a pastoral narrative approach. MA thesis in Practical Theology (Pastoral Family Therapy), Faculty of Theology, University of Pretoria. 
Meekers, D \& Calves, A E 1997. Main girlfriends, girlfriends, marriage, and money; the social context of HIV risk behaviour in sub-Saharan Africa. Health Transit Rev. 7 (Suppl), 361-375.

Muntingl, P 2004. Narrative counselling. Social and linguistic processes of change. Discourse approaches to Politics, Society and Culture. Amsterdam: John Benjamins Publishing Company.

Morgan, A 2000. What is narrative therapy? Adelaide: Dulwich Centre Publications.

Müller, J 2003. Unheard stories of people infected and affected by HIV/AIDS about care and the lack of care: The research story of the project. In: Practical Theology in South Africa 18(3): 1-20.

Nichol, R J \& De Klerk, B \& Nel, M M 2004. The role of HIV Denial and other factors in Health Promotion. Article awaiting publication.

O’Connor, M. 2005, 31 Maart. VS het meeste sterftes weens vigs. Provinsie in pandemie se wurggreep, sê UV-man op kongres. Die Volksblad, 4.

Sadock, B J \& Sadock, V A 2003. Sypnosis of Psychiatry. Behavioral Sciences/Clinical Psyciatry. $9^{\text {th }}$ Edition. New York: Lippincott Williams \& Wilkens.

Strebel, A 1997. Putting discourse analysis to work in AIDS prevention. In: Culture, Power \& Difference. Edited by Ann Levett, Amanda Kottler, Erica Burman \& Ian Parker. Cape Town: University of Cape Town Press, 110121.

Swartz, L 2002. Culture and mental health. A South African view. Cape Town: Oxford University Press.

Tangmunkongvorakul, A, Celentano, D D, Burke, J G, de Boer, M A, Wongpan P, Suriyanon, V 1999. Factors influencing marital stability among HIV discordant couples in northern Thailand. AIDS Care. 11(5), 511-524.

Terre Blanche, M 1997. The knowledge that one seeks to disinter': psychiatry and the discourse of discourse analysis. In: Culture, Power \& Difference. Edited by Ann Levett, Amanda Kottler, Erica Burman \& Ian Parker. Cape Town: University of Cape Town Press, 139-158.

Thiesmeyer, L 2003. Discourse and Silencing. Discourse approaches to politics, society and culture. Amsterdam: John Benjamins Publishing Company.

UNAIDS. 2005. Geographical area - By country: Country HIV and AIDS estimates, end 2003 (http://www.unaids.org/en/geographical+area/by+ country/south+africa.asp) 1-4. Retrieved from the World Wide Web on 31 March 2005.

Van Niekerk, E \& Prins, A 2001. Counselling in Southern Africa. A Youth perspective. Cape Town: Heinemann.

White, M 1993. Deconstruction and therapy. In: Therapeutic Coversations. Edited by S. Gilligan and R.E. Price. New York: W.W. Norton \& Company, 22-61. 